\title{
Abstracts of Papers Presented at the Fourteenth Annual Meeting
}

\section{The lapanese Communists and Their Struggle for Power} Paul F. Langer, RAND Corporation

In the forty years since its inception, the Japanese Communist Party (JCP) has made little headway on the road to power. This is due partly to an unfavorable local and international environment and partly to certain fundamental weaknesses of the Japanese Communist movement.

A major obstacle to Communist advances in Japan are the Socialists who are sufficiently far to the left to attract the anti-government vote, but not radical enough to enter into a united front with the Communists. The Japanese Communists have always looked for inspiration and strategic guidance to Moscow, and, more recently, increasingly also to Peking. However, neither the Moscow nor the Peking models are suited to conditions in Japan. Hence a dilemma for the JCP.

Since Soviet and Chinese Communist objectives in Japan are largely identical, the JCP could long avoid taking a position in the Moscow-Peking conflict. Today, the Party is being forced by circumstances to face the issue. Indications are that the Japanese Communists with considerable reluctance are beginning to think along more independent lines while seeking to maintain good working relations with both Communist power centers.

\section{Concepts of Political Power in Pre-Modern India}

Robert I. Crane, Duke University

The central thesis of the paper is that traditional views held by scholars regarding the nature of political power in pre-modern India require reformulation. The traditional view has stressed constitutional themes and problems of political legitimacy; it reflected the ethnocentric concerns of the older political science which emerged in the context of the western nation-state. Recent work by political anthropologists and by behaviorists stresses the complex interrelations between acts defined as political and those defined as social. Political mechanisms, it is held, are but part of a total set of social mechanisms for regulating various aspects of a society.

Seen in this light, the task is to conceptualize the Indian political system as a system of interactions. Thus one would study the relations between the state and the caste system or the state and the guilds. One would also define certain acts as both political and non-political, which roles-such as that of the king-must be seen in their various dimensions. Suggestions are then advanced for hypotheses which might prove valuable in re-thinking the ancient Indian political order.

Confucian Bureaucracy and the Allocation of Power Joseph R. Levenson, University of California, Berkeley

Chinese bureaucracy established its Confucian "mean" position after centuries of adjustment of relations be- tween aristocracy, monarchy, and bureaucracy. Aristocracy as a serious contender with Confucian bureaucracy in its own right, not just as an imperial auxiliary, was silenced from the Sung period on. Stricken now, aristocracy, the old Chou impediment to centralized authority (removed by Ch'in, seriously revived in the post-Han military conquests), moves to the side of monarchy; and bureaucracy, the Ch'in instrument of anti-feudal monarchy, confronts that power it had stiffened so well that now it stands alone, a bureaucratic Confucianism, as the only remaining countervailing force. The monarch, served by bureaucracy to such an extent that aristocracy is tamed, repels bureaucracy in some degree by his now unbalanced power. And Confucianists, who owed their corporate existence to imperial sponsorship in the teeth of aristocracy's hostility, take up the role of resistance when the aristocrats' teeth are blunted. Aristocrats, now the monarch's creatures, sound more and more like kept men, while Confucian officials strain to get out of the monarchy's keeping. And so while some aristocrats become Confucian enough to see themselves in a bureaucratic context, but approach a monarch's non-Confucian ideal of a bureaucracy of means, Confucianists take on some aristocratic color, conceive of themselves as ends in themselves, and set out to prise open the imperial clutch.

\section{Economic Models for Asia}

Walter C. Neale, The University of Texas

Harry W. Pearson, Bennington College

To analyze the general problem of change from a village to a national, industrial economy in Asia, we need sociological models. These must identify the substantive economic process (production and movement of material goods, or "locational movements") and the relations between economy and society (primarily the values and the appropriational rights and obligations which sanction movements of material means). Polanyi, Furnivall, and Riggs offer elements of such a model. Polanyi operationally defines the substantive economy and classifies economic activities according to the integrative pattern (reciprocity, redistribution, exchange) governing its appropriational sphere. As a model of transition, it needs to specify the elements of the locational sphere, their relation to the appropriational, and how the integrative patterns are related to other societal subsystems. Furnivall emphasizes the importance of common values, and the stresses and deterioration that occur in a plural society of conflicting values, but provides no institutional guide to the means of a new integration. Riggs' model of "bazaar" and "canteen" in a "prismatic" society moving from diffuse, fused institutions to functionally specific ones fits the cases of Indian administration and village development, but does not locate the economy or indicate how functionally specific but non-market institutions may arise in "refracted" societies. From the elements of models such as 
these, we have still to build a theory of socio-economic transition which accounts for all the variables and allows for the variety of possible re-integrated, stable destinations.

\section{New Research on the Chinese Paleolithic}

Hallam L. Movius, Jr., Peabody Museum, Harvard University

Significant research projects implemented by Chinese scholars during the past ten years at Choukoutien, at various localities in the Fen River Valley (Ting Ts'un, $\mathrm{Li}$ Ts'un, and Chiao-Ch'eng) and the Ordos region (Shuitungkou and Sjara-Osso-Gol) have brought to light a wealth of new information on the beginnings of Early Man in Northern China. At Choukoutien: Locality I, a new series of early deposits are yielding materials comparable in age with those previously reported from Locality 13. The first of the sites referable to the Fen Valley Complex (Ting Ts'un) was discovered in I953, and now comparable materials have been reported from two other very prolific localities in the same drainage basin. The precise geological dating of these horizons is as yet unclear; in broad terms they fall chronologically between Choukoutien: Locality 15, on the one hand, and the Fourth Glacial (Malam) loess sites of the Ordos, on the other. It is most heartening to learn that after a lapse of nearly forty years, investigations have been resumed at Sjara-Osso-Gol and Shuitungkou. Only preliminary notes describing the results of the first season's operations have thus far appeared. Both localities are extremely rich, and it will be interesting to follow reports as they appear in Chinese archaeological literature.

\section{Recent Findings of the Chinese Neolithic}

Kwang-chih Chang, Yale University

Stratigraphically and substantively important neolithic sites in North China excavated in recent years have provided significant data for a new interpretation of the formative cultures of the Huangho valley. Under the current view, a nearly complete sequence of cultural development can be reconstructed for the Huangho valley, from a stage of the first establishment of primary village farmers in the Nuclear Area (Yangshao), through a stage of explosive expansion of this Huangho culture into the eastern and southern lowlands and river valleys (the Proto-Lungshan complexes), to a stage of pre-civilizational local cultural traditions (the Lungshanoid phases of Shensi, Shansi, Honan, and the Pacific Seaboard). The Shang civilization subsequently emerged in the plains upon the foundation laid down during the neolithic period. Major problems that remain to be solved consist of the origin of the initial food-producing way of life in this part of the Old World and the absolute chronology of the entire sequence.

The Modernity of Sung Archaeology

Richard C. Rudolph,

University of California, Los Angeles

Because the Sung period was marked by intellectual freedom, exploration, and maturity, archaeological studies made a great leap forward at this time. The progressive attitude can be seen in the sound criticisms of contemporary archaeological works, which themselves were far in advance of similar work in Europe for centuries to come. The major works are the illustrated and descriptive catalogues, but a great amount of valuable archaeological writing may be found in notebooks, travel diaries, geographical and other minor works. Collecting and cataloguing was done on both the imperial museum and private scholar level, field work was making definite progress, and connoisseurship was rising to heights of heretofore unknown objectivity. Even a brief survey of Sung archaeology suggests that the collectors, field workers, and researchers employed, within the limits of the advancement of science at that time, most of the techniques used by modern workers in this field. A current intensive study will in all probability substantiate this suggestion.

\section{The Effect of Piece-Mold Craftsmanship on Shang Bronze Design}

Wilma Fairbank, Cambridge

China's earliest bronze vessels were, it is suggested, cast directly from clay pots by the piece-mold systema technique developed in China uniquely in the ancient world. Twenty-one per cent of the bronze vessels excavated pre-war at Anyang were entirely undecorated pottery shapes. Their sole distinction was the practical advantage of durability. The subsequent development of the superb plastic decoration feasible in metal is traced from simple bands incised in the piece-molds to high relief elements built up on the clay model where they are repeated or reversed mechanically by a stencil tech. nique. Flanges and protruding eyes are cited inter alia as design by-products of the piece-mold process.

\section{The Russian and Chinese Models}

\section{Donald S. Zagoria, RAND Corporation}

There has been an intermittent dialogue between Moscow and Peking since 1949 on the question of whose experience is more valid for other underdeveloped countries in Asia and elsewhere. This dialogue seems to be intimately related to a struggle for power and infuence both within and outside the Communist movement. The Russian "model" for building socialism has not proved adequate for an underdeveloped Asian country such as China with quite a different population-resource ratio, much less technology and trained manpower and a more primitive industrial base. Since I957 the Chinese have been seeking a "road to socialism" more in keeping with their own pressing and peculiar problems. They have not yet found the solution. Neither the Russian nor the Chinese "model," both of which have been shifting over the years, can be mechanically transferred to other environments, and it seems likely that smaller Communist states will increasingly pick and choose elements from both Russian and Chinese experience while adapting to their own peculiar conditions. Considerable work remains to be done by political scientists in the emerging field of comparative Communism. 


\section{JOURNAL OF ASIAN STUDIES}

Building Socialism in North Korea:

The Emergence of the "Korean Model"

Glenn D. Paige, Princeton University

This paper examined the question of whether the Korean Communists have followed the Soviet or Chinese "model" in the transformation of North Korean society since 1945. The main conclusion was that the Koreans have avoided defining the Russian and Chinese experiences in mutually exclusive terms. Rather they have developed a formula of "learning from the historical teaching of the Soviet Union and the practical experience of the Chinese Revolution in order to apply Marxist-Leninist theory creatively to the concrete conditions of Korea." Evidence was found for a general primacy of orientation toward (as distinguished from control by) the Soviet Union. Major parallels with Chinese experience were found in the area of agricultural collectivization.

\section{Communist North Viet-Nam}

\section{Bernard B. Fall}

The North Vietnamese Communist regime is thus far the only communist government to have been able to impose its rule entirely "from within" (since even Yugoslavia and Red China at least enjoyed propinquity with Soviet forces during their struggle). This, along with the fact that its army is the strongest in Southeast Asia, gives it a somewhat special place within the communist state system.

Another interesting characteristic of Ho Chi Minh's regime is that it has thus far survived without a permanent "purge" of any of its leaders, in spite of the fact that it contains two strongly opposing wings within its ranks, one turned toward Peking and the other-considered to be in the saddle at present and grouping such major leaders as Ho Chi Minh, Vo Nguyen Giap and Pham Van Dong-oriented towards Moscow.

In the economic field, the North Vietnamese regime has made all the errors in the field of agricultural reforms that are usual under that form of government, but apparently has been fairly successful in its relations with the mountain minorities in the country.

In terms of foreign relations, it is more isolated from non-communist Asian states than it was when it still fought against the French, but this appears to be part of a deliberate policy on the part of its leaders.

\section{The Mongolian People's Republic}

Robert A. Rupen, University of North Carolina

The Mongolian People's Republic, an Asian member of the Communist bloc, clearly continues to be influenced far more by Russia than by China, even though China does extend some aid. Russia to a considerable extent controls Mongolian foreign policy and offers the model for many Mongolian domestic institutions and methods. However, the USSR has not injected vast amounts of economic assistance, and economic development has been fairly slow and undramatic. Livestockraising continues to dominate the economic life of the country and most of the limited and light industry relates to handling and processing livestock products. The most significant changes resulting from Communist rule have been the destruction of the Buddhist Church and the construction of a working and near-universal educational system. The illiterate, syphilitic, superstitious, dirty Mongol has practically disappeared. Old Mongolia is gone forever. Mongols are healthier, and Mongolian society is probably healthier, as well. The positive gains of education and health must be balanced against purges and destruction, secret police, and "socialist realism." But the Mongolian urge to independence continues to be powerful, and Mongolian resistance to Russian and other foreign manipulation is strong and sometimes effective.

\section{How Economic Growth Begins: A Theory of Social Change}

Everett E. Hagen, Massachusetts Institute of Technology

Authoritarian personality, hierarchical social structure, and dominance of the physical environment over human affairs characterize traditional society. They combine to re-create authoritarian (uncreative) personality, generation after generation, and thus to perpetuate the other conditions as well. These conditions breed into members of the elite, even if they are creative, repugnance to being associated with manual-technical work. This prevents technical progress.

This stability of the traditional social order is disrupted when historical developments cause members of a group of the lesser elite to feel that their erstwhile respected status is derogated. They then feel anxiety, rage, and helplessness. These reactions cause changes in their behavior in the home which result in changes in the personality of the next generation. Over several generations, increasing "retreatism" or anomie appears, especially in the males, and then, in a subsequent generation, creativity plus alienation from traditional values appear. Emergence of such a group has always tended to result in social change of some sort. In the circumstances of the modern world, it tends to cause a transition to continuing economic growth.

\section{Achicvement Motivation and Economic Development in Southeast Asia \\ David C. McClelland, Harvard University}

The concern for achievement among significant élites is related to rate of economic growth in Southeast Asia as it has been in the past in Europe and is now in other parts of the world. For example, the amount of such achievement concern is markedly higher in current Communist Chinese third grade readers than it was in similar readers from Republican China a generation ago. It is argued that the content of these stories accurately reflects the concern of an educational politicaleconomic élite which in turn affects the rate of economic growth-which is much higher in China today than it was in the 1920's, just as the reader data would predict.

Value Systems and Economic Performance in Japan and Thailand

Eliezer B. Ayal, University of Michigan

In spite of many historical similarities in her exposure to the West, Thailand has remained at a much 
lower level of economic development than Japan. Many of the factors, economic and institutional, commonly regarded as responsible for the Japanese success were present in Thailand as well. A comparative study of the two countries during the second half of the nineteenth century reveals that a crucial difference between them was in their value systems.

The effect of value systems on economic performance can be best shown through the intermediary of economic propensities: to accumulate, to innovlate, to work hard, and to cooperate. The Japanese value system encouraged economic development both by providing goals which could be promoted through increased production, as well as by sanctioning and promoting the means-namely the propensities. The Thai value system failed to provide such incentives for economic performance. The emphasis of the Japanese value system on initiative and active fulfillment of one's duties stood in clear contrast to the almost complete freedom of the Thai from worldly obligations. It is argued that political and economic measures will not bring about economic development unless the value system is conducive to such change.

The Subordinate State System of Southern Asia

Michael Brecher, McGill and Yale Universities

The concept of Subordinate State System requires six conditions: (I) Its scope is delimited with primary stress on a geographic region. (2) There are at least five actors. (3) Taken together, they are objectively recognized by other actors as constituting a distinctive segment of the Global System. (4) The members identify themselves as such. (5) The units of power are relatively inferior to units in the Dominant System. (6) Changes in the Dominant System have greater effect on the Subordinate System than the reverse.

There are four structural features of the system: (I) the low general level and fragmentation of power; (2) acutely underdeveloped organizational integration; (3) bilateralism and infrequency of interaction; (4) continuous penetration by the Dominant bipolar block System. Some tentative conclusions flow from this analysis. Southern Asia bears a striking resemblance to the Balkans before rgr4. The real danger in such an unstable system of power is that one or more of the units will disintegrate or come under the control of outside states. If this were to occur in a unit like India, probably nothing could prevent China's domination over the whole system.

\section{The Malayan Confederation-One Answer to Balkanization}

Frank H. H. King, Washington, D. C.

Political unions are under stress; thus the probability of a Malaysian Federation including Malaya, Singapore, and the three British Borneo territories is welcomed by those concerned about the proliferation of sovereign units.

Any union implies sacrifice by the component parts, and Malaysia despite the seeming logic of its conception is no exception. Although there are cultural, economic, and political reasons for Malaysia, the immediate motivation is Malayan fear of a Communist Singapore. The present Federation therefore accepts union but demands political containment of the Singapore Chinese; Singapore's cconomically motivated government accepts restriction but must minimize its significance. The compromise is comparable to that of the United Kingdom with Northern Ireland, with lower federal representation justified by greater Singapore autonomy in education and economic organization. Malaya seeks the Borneo territories to further redress the communal balance, but Borneo fears neglect and requires assurances.

The probable success of the union proposals can be attributed not to racial, cultural, or colonial background but to politically reasonable leadership and some willingness to accept compromise. These attributes need not be restricted to Malaysia.

\section{Causes of the Partition of India Re-examined \\ Vasant D. Rao, San Diego State College}

Looking back at the events which preceded the partition of India, I conclude that it would have been difficult, if not impossible, to avoid partition. In my view, the causes of partition were: (I) The Muslim's Pan Islam attitude, their sense of superiority, their distrust of the Hindus, and their ever-increasing demands; (2) The British policy of separate electorates and their divide and rule tactics; (3) Mr. Jinnah's great ego and his frustration; (4) The failure of the Indian National Congress to rally the Muslim League and their playing into the hands of Mr. Jinnah.

\section{Abu'l Kalam Azad's Theory of Nationalism Hafeez Malik, Villanova University}

Azad's life (1888-1958) can be divided into two distinct phases: Muslim Nationalist (r906-1920) and Nationalist Muslim (1922-1958). As a Muslim Nationalist, he believed in the cultural entity of a Muslim nation in India and worked for its separate political destiny. His policy was lack of trust in Britain and non-cooperation with the Hindus. His nationalism was extra-territorial and embraced Muslims all over the world. Azad considered himself a citizen of the "Turkish Caliphate"; when the latter collided with Britain during World War I, he declared his loyalty to Turkey and sanctioned Hindu-Muslim collaboration because it helped the Caliphate.

After World War $I_{1}$ Azad's views radically changed. Ataturk abolished the Caliphate, and Arab nationalism based on "common heritage" swept the Middle East. Azad accepted these secular and territorial nationalisms and applied their principles to the Indian political situation. He referred to the Covenant of the Prophet Muhammad between the Muslims and Jews of Medina ( 622 A. D.). Its preamble stated: "This is a document from Muhammad, the Prophet, between the believers and Muslims of Quraish and Yathrub [Medina], and those who followed them and labored with them. They are one community [Umma-i-Wahida] to the exclusion of all men" (Guillaume, Kitab Sirat Rasul Allah, trans. Oxford, 1955, p. 232). Azad translates Umma-i-Wahida as "together we constitute a nation," and then draws the conclusion that if the Jews of Medina could constitute a nation with the followers of the Prophet, cer- 
tainly Muslims and Hindus could create a joint Indian nationality.

\section{Indian Nationalism: A Revised Definition}

Charles H. Heimsath, American University

Nationalism may be defined, in the case of India, as an attitude of mind (or set of beliefs) shared by a group of people large enough to be influential which embodies ideas of the nation and the nation's goals, elevates those ideas to a prime position over other values, and compels the assertion of the identity and aims of the nation. Since the 1880 's there have been competing nationalisms in India, each based on a different definition of the nation. All-Indian nationalism's definition was and is based on Western concepts which appealed chiefly to English-educated groups. Popular participation in nationalism was achieved when the nation was defined, explicitly or not, in terms of a region or a religious community or social group. Although the Western idea of the nation-with its liberal, secular, and egalitarian state-was frequently challenged in the National Congress during the twentieth century, it survived and forms the basis of the modern Indian Constitution. That idea is still being challenged in India today by those who define the nation as a religious-cultural or a linguistic-regional community.

\section{The British and the Moneylender in Nineteenth-Century India}

Thomas R. Metcalf, University of California

With the imposition of British rule upon India, the moneylending classes acquired an unprecedented degrce of power in the countryside. Humble dependents of the village community, they made themselves, with the assistance of British contract law and the British judicial system, into masters of the peasantry. The British viewed this social upheaval with extreme distaste. Yet it flowed from the very nature of the political system, and they could see no way of stopping it, short of repudiating that system and the principles of freedom of contract and security of property upon which it was based. This they were unwilling to do, even when the disruptive effects of land transfer were made patently clear during the popular uprising of i 857 . The Deccan riots of 1875 , directed specifically against the moneylender, prompted the British to enact a first and minimal measure of relief for the peasantry; but only in the twentieth century, as laissez-faire liberalism began to lose its hold over the English mind, did they act decisively-to prohibit land transfer in the Punjab and to establish co-operative credit societies throughout India.

\section{Ou-yang Hsiu and the Transition of Sung Neo-Confucianism}

James T. C. Liu, Stanford University

Ou-yang Hsiu (1007-1072), a towering figure in so many different branches of learning and accomplishment, was respected by the Southern Sung and the Yüan scholars as a model essayist, a comprehensive scholar, and an outstanding statesman, but not among the greatest masters of Neo-Confucianism. This estimation has not taken into full account the nature and the circumstances of the pioneering period during the Northern Sung. Nor has it pointed out that the pioneers such as Ou-yang did fail in some significant ways. The revival, or rather the new growth, of the ancient style essays opened the floodgate of divisive opinions; these pioneers ${ }^{3}$ interpretations of the classics added fuel to factional controversies, and their success in administrative improvements could not save the general deterioration of the political conditions. It was in part the frustrations in these areas that led the succeeding generations during the Southern Sung to seek advancement in a new direction, toward the well-known Neo-Confucian orthodoxy.

\section{A Case of Conceptual Change \\ Cho-yun Hsu, University of Chicago}

Ideology, as in the case of the change from the familial relationship of Chun Chiu society $(722-464$ B. C.) to the contractual relationship of the Chan Kuo society $(463-222$ B.C.), facilitates changes in social structure, in economic development, and in other conceptual areas.

Chinese feudalism of the Chun Chiu period, the political counterpart of the family network, disintegrated because of the power struggles among the states. This bloody strife among kinsmen started no later than the seventh century B. C.

One century later the traditional concept was changing, and in the Chan Kuo period, the dominant conception was one of contractual relationships. Status or birth did not determine a person's relationships with others; these were voluntary associations based on selfinterest and reciprocity.

This change encouraged social mobility, removed the authority of tradition, and recognized the profit-oriented mind which was indispensable for commercial development. New ideas were introduced by the many schools of thought of the Chan Kuo period, when tradition was being questioned. The widespread use of metal coins of various mints, indicating commercial activity, started in the fifth and fourth centuries B. C. Thus we witness ideological change and its association with other correlated changes.

Diplomacy and Intervention in the Developing Countries

William Henderson, Council on Foreign Relations

It is obvious that the external responsibilities and interests of the United States have grown tremendously over the past few decades, especially with respect to the newly emerging countries of Asia and Africa. But while the function of our diplomacy has thus been revolu. tionized, the concept of diplomacy remains to an undefined extent imprisoned within traditional molds. The result is a kind of schizophrenia which militates against the effective conduct of our relations with the newly emerging countries.

The prevailing concept of diplomacy is overly limited by the traditional doctrine of non-intervention and does not adequately take into account the demands of modern practice. We are really engaged in assisting the process of nation building. A new concept of constructive diplomacy, essentially manipulative in content, is urgently 
needed to redefine the objectives of United States foreign policy in the developing countries and the means by which these objectives may be pursued most effectively.

The Delhi Urban Area As Prototype: Some Comparisons with Other Large Indian Urban Areas

Gerald Breese, Princeton University

Existing and expected urbanization in India underlines the critical importance of research relevant to the preparation of comprehensive master plans for urban development. Part I examines the Delhi urban area as a possible prototype for other large Indian metropolitan areas. The study of Delhi--and comparisons with Bombay, Calcutta and Madras-includes consideration of the overall pattern, each type of land use, each areal component (Old City, Civil Lines, Cantonments, special housing areas, bustis and village enclaves, and "western" additions), indigenous and "foreign-born" patterns, regulation of expansion, by-passing of growth stages, and conurbation aspects. Part II focuses on research prerequisite to comprehensive master planning. Special attention is directed to transferability of theory and knowledge based on studies of western urbanization, the applicability of existing urban research techniques, as well as urgent data and map requirements. The comparative analysis of the structure and growth of large urban areas emerges as meriting highest priority.

\section{The Growth of Large Cities in India}

John E. Brush, Rutgers University

The preliminary results of the $196 \mathrm{r}$ census show that the rate of urbanization has decreased since $195 \mathrm{I}$ in comparison with the decade $194 \mathrm{I}$ to $195 \mathrm{I}$. The percentage of total population in urban places increased from 17.3 in 1951 to 17.8 in 1961 . All towns and cities increased only 26 per cent, while the population in India as a whole gained 22.3 per cent. However, statistical comparisons must be used with caution because of $196 \mathrm{r}$ changes in the census definition of "urban," which affects the classification of small centers.

Large cities, i.e., metropolitan agglomerations with I oo,000 or more inhabitants, generally gained less than 40 per cent and the majority did not achieve growth rates equalling or exceeding the rates of increase from I94I to $195 \mathrm{I}$. It is clear that cityward migration, which was accelerated in the previous decade by war, partition, and independence, has now slackened, although in some cities growth is occurring in a spectacular fashion.

The diminished rate of urban growth may be ascribed to the relative lag in India's economic development and the severe overcrowding in existing urban areas where population previously doubled in one or two decades without commensurate expansion of housing and other facilities.

\section{The Characteristics of lapanese Cities}

David H. Kornhauser, State University of New York

Since October 1953, Japanese census data have lost meaning in measuring city growth because of government pressure for amalgamation which enlarged most city areas, incorporating vast amounts of non-urban settlement. For the 1960 Census, however, government statisticians and others have evolved an accurate means of delineating heavily-populated areas by using certain census enumeration districts (rather than administrative areas) as criteria of measurement. The new units, called Densely Inhabited Districts, henceforth will provide data along with the "normal" census.

The 1960 preliminary reports of Densely Inhabited Districts thus show these differences from the regular census: ( $\mathrm{r}$ ) The nation is 43.7 percent densely inhabited, compared to 63.5 percent in cities by ordinary census count. (2) The degree of density seems generally related to city size, the larger cities being more densely inhabited than the smaller. (3) The four major metropolitan areas contain a greater segment of the whole population than is seen in normal tabulation. (4) Regional analysis shows lower than average densities in Tohoku, Hokuriku Tozan, and Chugoku-Shikoku, and higher elsewhere. (5) Greater densities and perhaps more vigorous growth since 1950 are suggested for cities with maximum physical accessibility.

\section{Political Aspects of the Imperial Institution in the Tokugawa Period \\ Herschel Webb, Columbia University}

Tokugawa period thought on the function of the Japanese imperial institution characteristically proceeded from the assumption that the Emperor was in some sense central to the nation. Yet, practically no thinkers of this "loyalist" tradition described clearly what they believed was the ideal relationship between the imperial office and the effective government. This paper attempts to show that there was present in the thought of the same writers a tension between two contrary attitudes. According to one, the Emperor, who had once had secular powers, had delegated them to the shogunate. Hence, by implication, he could rightfully redelegate them or reassume them himself. According to the other, the Emperor's powers were essentially religious or moral. As a symbol of national values, he defined the standards by which the government ought to rule, but he could not in any practical sense alter the fact that the government did rule. The incompatibility between these attitudes was not obvious until very late in the Tokugawa period; only after the Meiji Restoration could peo ple look back and say unequivocally that the Emperor had potentially been a secular ruler all along.

\section{The Japanese Emperor: Some Political and Constitutional Changes}

\section{W. M. Tsuneishi, Yale University}

The Emperor, as characterized in the Meiji Constitution, is an absolute monarch, at once generalissimo and chief civil magistrate. In actual practice, modern Japanese emperors, and particularly the reigning monarch, have acted more in the British style. Hirohito was trained to accept without question policies decided upon by his military and civilian advisers. At the end of the war, when his advisers could not agree on the question of surrender, he moved from his accustomed role of passive puppet to participate actively in the formation of the surrender decision.

Under the present Constitution, the Emperor is re- 
duced to the status of symbol of national unity, whose functions in matters of state are chiefly ceremonial. While the theoretical change has been of vast proportions, the actual change in his position has been of lesser magnitude. In fact, it may be concluded that the change is largely a formalization and codification of the actual role played by modern Japanese emperors as limited monarchs in the British pattern.

\section{Popular Attitudes Toward the Emperor}

Takeshi Ishida, Tokyo University

The paper deals with the historical change in popular attitudes toward the Emperor in postwar Japan, using the results of public opinion polls. The results of polls taken in different years are compared and their implications are analyzed, according to the social context of the time.

The second part of the paper analyzes the social basis and political function of the present popular support for the Emperor, which is essentially nothing but a vague emotional attachment to him.

\section{Dutch Civil Service in Indonesia in the Two Decades Preceding 1942}

Boyd Compton, The Rockefeller Foundation

The principal aspects of Dutch colonial rule in Indonesia before 1942 are often obscured by respectable myths concerning "non-interference in native institutions," "indirect rule," and "decentralization." If we study Dutch rule as a system of authority in action, we can infer the following five trends: (I) The system of authority in colonial Indonesia was becoming extraordinarily intensive; as a result, native institutions were undergoing basic transformation. (2) The exercise of authority was becoming legalized, i.e., subject increasingly to explicit directives. (3) Functional differentiation of authority was creating an elaborate regional bureaucracy; coordination of government action was becoming difficult. (4) No significant decentralization of authority was taking place. (5) The system of authority was rapidly becoming uniform throughout the islands. These principal trends continued after 1949 , but the authoritativeness of government decreased in a society which had become enlivened, expectant, and more obstreperous after independence.

The Role of the Colonial Services in the Administrative and Economic Development of Malaya

Robert O. Tilman, Duke University

Based primarily on research in the field, this study reviews the historical evolution of Malayan bureaucracy, examines the formal and informal colonial bureaucratic legacy, and suggests the role of the colonial services in the evolution of the present Malayan economic system. The paper argues that the present bureaucracy is a direct descendant of the British colonial model, and that this is reflected in the institutional framework and in the continuation of certain attitudes that might logically seem unique to a colonial system. The paper further demonstrates that in the process of transplantation, however, certain functional mutations have occurred. In the final section the paper points out that the economic legacy is equally apparent, though in this sphere the co- lonial services primarily sought to create the conditions conducive to economic advancement and then largely stood aside to let the process take its own course. The study concludes that, while many of Malaya's internal problems may stem from its colonial experience, without this background present-day Malaya would not be "modern" Malaya.

\section{The Changing Concept of the Recluse in Chinese Literature}

Li Chi, University of Michigan

The recluse emerged at the dawn of Chinese history, side by side with the man of action. This unique fact reveals an indigenous concept which budded in the earliest time of conscious thought; it explains the split personality of the Chinese intellectual and his strong sense of two worlds. Throughout the long course of Chinese history, the concept of the recluse, influenced in turn by Confucian, Taoist, and Buddhist thought, and in response to social changes, underwent a series of changes. Yet, notwithstanding the sophistication of the idea of the recluse by theoretical justification and the exploitation of the concept by rulers as well as by some self-styled recluses, the concept of the recluse in its purity and essence never ceased to haunt the mind of the Chinese intellectual and monopolize much of the spirit of Chinese poetry.

The Chün Tzu in the Analects of Contucius Compared with the Concepts of the Ideal Man in Greek and Christian Thought

W. Scott Morton, Edinburgh University

Confucius is mainly responsible for the transfer in the meaning of the term chün tzu from the original aristocratic sense of "son of a prince" to the ethical sense of "a gentleman" bound by a particular code of morals and manners. On analysis, sixty-five instances of the use of the term in the Analects yielded eight groups of adjectives of quality: resolute, mild, marked by "reciprocity," slow to speak, making a study of "ritual," conscious of failure, trustworthy, independent.

Confucius is to be compared to Socrates in his concern with the training of youth and to Plato in his search for the philosopher-king. He shows affinity with the Greeks in his emphasis on self-control and independence, and on knowledge in the moral as well as the intellectual sense. Similarity between the Confucian and Christian view is seen in insistence on moral standards for the individual and for society. The difference is seen in the source of moral power, and this involves basic motivation-so much so that no one figure type corresponding to the chïn tzu emerges in the Christian ethic. For Confucius the object is the cultivation of goodness; for the Christian the object is deliverance from self-centeredness to fulfil the purpose of God, with goodness as a by-product.

The Yüan-hun chih "Essays on Ghosts with Grievances": $A$ Collection of Stories of the Sixth Century

Albert E. Dien, University of Hawaii

The Yïan-hun chih, by Yen Chilh-rui (531-ca. 591), is an example of the genre of short story of the Six Dynasties, and merits study as a unique source of material 
on the history and society of the time. While the modern text has been generally considered an integral one, it can be shown that it was copied from the T'ang encyclopedia Fa-yüan chu-lin, probably by Ch'en Chi-ju who first printed it in 16 5 . Modern critics have classified the collection as Buddhist propaganda, but comparison with other, obviously Buddhist stories, reveals little similarity. The traditional theme of retribution by ghosts had been taken up by Confucians with Buddhist commitments; to class these stories as Buddhist serves to obscure the intellectual position of Yen and other literati of his time.

\section{How Buddhistic is Wang Yang-ming? Wing-tsit Chan, Dartmouth College}

Wang Yang-ming (1472-1529) has been attacked as a Zen Buddhist in Confucian disguise because he used many Zen expressions, told many Zen stories, applied some Zen techniques, visited many temples, and equated his "innate knowledge" with the Buddhist "recognition of the original state." But unlike the Sung Neo-Confucianists, he had no Buddhist friends and quoted only once from a Buddhist scripture in his Ch'uan-hsi lu. His meeting with the Japanese priest, Keigo Ryōan (1425-1515) was casual and brief, if it took place at all. His criticisms of Buddhism, concentrating on the Zen doctrine of the mind, are stronger than those of the Sung Neo-Confucianists. He offered four arguments: (I) The Zen doctrine of the absence of thought about good and evil is untenable because an unthinking mind is no mind. (2) Since the Buddhists avoid social relations, their claim of non-attachment to things is really attachment to selfishness. (3) The Zen sudden enlightenment through seeing one's own nature is impossible because the mind cannot fully function except in actual affairs. (4) The Zen mind is incapable of handling the world because it is an abstraction. In short, in emphasizing the function of the mind, Wang went beyond Chu Hsi (1130-1200) who criticized the Buddhist theory of the mind in terms of its substance.

\section{The Philosophy of Mind as a Form of Empiricism}

Vincent Y. C. Shih, University of Washington

This paper, while taking as its point of departure the philosophy of mind in postulating as primary facts the mind and the field, formulates a synoptic view of life in all its stages of development. By giving the term "experience" a wider scope in applying it to all the realms which result from life's Odyssey through the field-the intellectual, the aesthetic, the moral, the religious as well as the sensory - a system of empiricism is proposed in which the various realms enjoy their unique status with their unique principles and laws, each realm related, though not reduced, to the other in an ascending scale both in the existential order as well as in their significance in revealing the creativity of the mind. The creativity of the mind becomes greatest when it is its own field, enjoying complete spontaneity and freedom, a necessary condition for creativity.

Through creativity the mind seeks ever to break through its own finitude to reach a greater whole. The absolute whole, while unattainable, is present in finite experience, an inspirational ideal that forever beckons us onward into ever higher and greater realms.

The Pattern of Philippine Economic Growth, 1945-1960

Frank H. Golay, Cornell University

The Philippine economy, a modified enterprise system highly dependent upon individualism, has experienced rapid economic expansion over the postwar period. A prominent feature of this growth has been the structure of entrepreneurial incentives, largely reserved to Filipinos, arising out of such diverse influences as currency overevaluation, establishment of Philippine commercial policy autonomy, tax exemption privileges, credit allocation policies, Japanese reparations, and ag gressive Filipino economic nationalism.

Equally important in explaining the upsurge of entrepreneurial activity has been the rapid expansion in agricultural production which is essential to understanding the political, social, and price stability of the past decade. Agricultural expansion has interacted with rapid urbanization to provide entrepreneurs a highly elastic supply of labor at minimum, semi-subsistence wages. Finally, the unusual tenderness toward entrepreneurial expectations built into the Philippine economic organization is reflected in the regressive tax system.

\section{China's Industrialization: Fact, Fiction, Speculation}

\section{Sidney Klein, Rutgers University}

In absolute terms, in agricultures, industry, and transportation, productive capacity has been enlarged. This is a fact which all of the discussion concerning the undesirable non-economic aspects of Chinese Communism cannot eradicate. However, while China's productive capacity has been enlarged since 1949 , it has not been enlarged by anything like the extent pictured in the statistical data issued by Peking. Further, China has not had and does not now have the economic "defense in depth" necessary to keep industrial facilities in operation most of the time. The figures in "The Great Ten Years" and other such publications clearly overstate China's economic growth and current strength. With keen awareness of the great variability of the factors in volved, I will go on record as believing that the next $2 \mathrm{r}$ months will see China's economic problems being intensified. Even if the 1962 harvests should be good ones, given the currently low levels of China's food, foreign exchange, and other reserves, the amount of investment possible in 1963 would be limited by the need to replenish these reserves.

\section{Militia in China during the Taiping Rebellion Philip Kuhn, Harvard University}

Two main types of local irregular force in nineteenth century China were t'uan (or militia) and yıng (or volunteers). The two were theoretically distinct: the $t^{\prime}$ uan, publicly controlled, non-professional, locally based; the yung, privately controlled, professional, and mobile. Most local militia units represented points along a continuum between these two polar types.

Theoretically the tuan had both police and defense functions. But during the Taiping Rebellion, internal control was often emphasized over external defense. Study of the form and function of militia units, as in. 
dicants of social division and cohesion, may be useful in determining the revolutionary momentum of the Taiping movement in different times and places.

\section{China's Resistance to Japan's Early Colonial Venture in Taiwan, 1874}

Leonard Gordon, U. S. Department of State

A study of the diplomatic events pertaining to the Japanese expedition to Taiwan, 1874 , reveals that internal and external factors in Japan pressured both for and against a war with China. The influence of the dissident samurai of the former feudal domains in Kagoshima, who sought a foreign military venture, has been generally considered a prime motivation for the expedition. Political and military leaders in Japan had divided into two factions: one desirous of war and the other advocating peace.

External elements that exerted their influence for war included military and legal advisers from the United States and Europe. The former American Consul in Amoy, Charles W. LeGendre, was most influential. However, American and British representatives in Tokyo and Peking served as a restraining element and were instrumental in preventing war.

Both nations were unprepared for a general war, but China's momentary build-up, supported by foreign assistance and foreign restraints placed upon Japan, were primarily responsible for a peaceful solution.

\section{Interpolation and Deletion, A Study of Chinese Historiography}

Lo-shu Fu, Los Angeles

Liang Ch'i-ch'ao (1873-r929) wrote that forgery first developed in China. However, since China is an ancient nation having many historical works, it is inevitable that both interpolations and deletions should occur during the long course of transmission from manuscripts to printed works. Interpolations were made to enrich the original, to revise it for greater accuracy, and to bring the information up to date. Deletions were made to save printing costs, to avoid offense, and to cut out ambiguous parts.

These were all done with the best of intentions, except in the case of Huang Tsung-hsi $(1610-1695)$. He seems to have adapted and appropriated two essays written by Teng Mu with no acknowledgment to Teng. Furthermore, the title of his book Ming-i Tai-fang Lu ("Awaiting a Visit from the Emperor") seems to have been inspired by Teng's Chien Yao Fu ("An Audience with Emperor Yao"). Because Huang's book enjoyed immense popularity, it seems only just that Teng deserves due recognition in the future.

\section{The Application of Research to Economic Policies in Developing Societies}

\section{J. B. Condliffe, Stanford Research Institute}

Technology has been associated with capital, but the transfer of capital alone does not develop technical and managerial skills. Industry can devise ways to transfer skills, but these cannot operate without some measure of law and order. It is necessary also to create an infrastructure of public utilities and services before production and distribution can be effective.
Allocation of inadequate resources among competing uses is essentially a decision for the developing countries themselves. It involves detailed study of the local environment. Advice by transient economists is often based upon preconceptions drawn from already developed economies. But adaptation to local conditions should not degenerate into refusal to face economic realities.

A visiting economist can help to augment the supply of nationals competent to decide policy and help them to grapple with the complexities of actual production and marketing as well as fiscal and monetary problems. He can adapt sampling and other techniques of measurement to improve existing data and add new data, test results by comparison with those obtained elsewhere, and insist upon rational explanation of local divergences. By drawing upon history, comparative experience, and observation, he can emphasize the importance of imponderables that cannot be measured.

\section{Economic Development Under Conditions of Guerrilla Warfare: The Case of Viet Nam}

James B. Hendry, Michigan State University

The conclusion of this paper is that economic development is difficult or even impossible under conditions of guerrilla warfare. Resources that South Viet Nam can ill afford to lose at its present rates of capital formation have been allocated to defense and security. Whether more capital could have been invested than has been is not completely clear, but most government efforts to encourage development have been blocked by guerrilla actions at the province level and lower, and the effects of this on potential industrial investors in Saigon and the few other urban areas are obvious. Unless a much greater effort at capital accumulation is made in the future, the country will not experience real economic growth. In looking at possible offsets, whatever the military's role may have been in other undeveloped areas, it does not emerge as a force for change and innovation in South Viet Nam. As long as the guerrillas remain active, South Viet Nam's major efforts will probably be military efforts, and if this is the case, these efforts can provide only a breathing space at best. Lasting military and political security cannot be gained at the expense of economic development, and it may be too late to do very much about the latter.

\section{A Comparison of Economic Progress Among Southeast Asian Countries}

Douglas S. Paauw, Yale University

In Southeast Asia, with a present population of about 215 million, rapid growth of real income per capita ( 2 per cent per annum or more) occurred only in the Philippines during the past decade, affecting about 13 per cent of the area's total population. Stagnation over the decade as a whole occurred in Indonesia with 96 million people (about 45 per cent of Southeast Asia's total), and the economies of Vietnam, Laos, and Cambodia also failed to raise per capita income. Burma showed slow progress, but her per capita income is still near the pre-war level. Thailand and Malaya made some gains, but their achievements during the 1950's can hardly be described as rapid economic growth. Apart from Indonesia, these discrepancies are not closely 
associated with differences in capital formation. The significance of economic determinants has been overshadowed by two broad categories of non-economic factors: (I) political stability and national unity; and, (2) conditions affecting the expression of human agents in economic development.

\section{Economic Development and the Use of Energy Resources in Communist China}

\section{Y. L. Wu, University of San Francisco}

This paper deals with the regional pattern of demand for energy products and their corresponding supply. It examines the problems of choice between thermal and hydro power plants, the latter being subject to the constraint of fixed locations, and the policy shifts during the first and second five-year plan periods. The discussion includes comparisons of initial outlay and operating costs of the two types of power stations in Communist China and an assessment of the role power development has played in the country's industrial development.

\section{Some Aspects of Pre-Industrial Urbanism in Japan} Robert J. Smith, Cornell University

For the cities of late Tokugawa Japan, little attention has been given data which throw light on the question of mobility. In support of the contention that pre-industrial Edo, Kyoto, and Osaka were urban centers in which mobility was very great, I have cited the annual registration called shümon nimbetsu chö for three districts in Kyoto for the years $1786-1867$. The figures, drawn from the published papers of Nakano Takashi and Yokoyama Sadao, reveal high rates of turnover in residential patterns and short duration of households. For example, about eighty-seven per cent of the households registered for the eighty-two year period have "life spans" of ten years or less; ninety-one per cent of the house-heads for this period are first-generation heads, and less than one per cent are fifth generation.

The member houses of the largest houses (those with the greatest wealth and largest number of bunke and bekke) show a greater tendency to persist than do small independent households. I have attempted to show that the pattern movement of individuals and households in a swiftly changing scene, so often cited as characteristic of early Meiji, was no stranger to the townsman of late Tokugawa.

\section{The Village-City Network in Indonesia}

Edward M. Bruner, University of Illinois

One recent trend in the comparative study of urbanization has been an enlargement of the scope of inquiry from an almost exclusive concern with intrinsic characteristics of the city itself to a consideration of the urban center in its regional and national setting. The unit of analysis is no longer a particular city viewed as an isolated system but is rather the entire network of social relationships between those who reside in the city, the surrounding peasantry in the hinterland, and members of the larger world community. This approach is particularly applicable to the emerging cities of Asia.

One such city is Medan, located on the east coast of north Sumatra, Indonesia. Three major characteristics of Medan are: (1) its newness; (2) its extremely rapid population growth due to migration; and (3) the resulting linguistic, social, and cultural heterogeneity of its population. In such a city one finds the following sociocultural concomitants: ( $I$ ) close ties between urbanites and their rural relatives; (2) an intensification of ethnic identity in the city; and (3) the formation of urban clan and ethnic associations which serve a variety of welfare, security, ritual, and political functions.

\section{Village Relations with Town and City in Cambodia May Ebihara, Bard College}

In discussing "urbanization," defined here as the city's impact upon the countryside, one notes that the village may have varying types and frequency of interaction with the town and city. In the village studied, there were frequent trips to the nearby town which had a market and shops, a school, and the district administration. Journeys to the city (Phnom Penh) were made by some individuals, primarily for temporary urban $\mathrm{em}$ ployment or to visit relatives; the city also held other significance as the nation's capital and embodiment of urban life. There was increasing use of manufactured goods (limited by poverty) and aspiration for whitecollar occupations (hindered by insufficient opportunity). But the village still retained a self-sufficiency in many respects, and interaction was most frequent on an intra- or inter-village level. A basic parochialism in village outlook was also strong, evident in ambivalence toward the city and distrust of unfamiliar communities.

From Boss to Broker: The Changing Role of Headman in a That-Lue Village

Michael Moerman, Yale University

The structural position and formal responsibilities of headmen in the nineteenth century in modern Central Thailand and in an isolated Northern village are similar. Yet there are great differences in role recruitment, about which comparable information is available, and in other aspects of the behavior of headmen. The differences result from alternative distributions of power between the local community and the national state. Only in the modern Northern village does the power distribution make the headman a "broker," as defined by Eric Wolf ("Aspects of Group Relations in a Complex Society: Mexico," American Anthropologist, LVIII (1956), 1075 f.). But, by rejecting his office, the headmanbroker differs from political brokers in Africa and Mexico. The basis of this difference is that the national power structure in Thailand does not depend on support from local communities. Thus, there is no exchange of political allegiance for valuables which the broker can monopolize.

\section{The Second Face of the Indonesian Revolution: Domestic History 1945-50}

John R. W. Smail, Cornell University

Tendency to view the Indonesian Revolution as only an anti-colonial struggle obscures important developments within Indonesian society. Fluctuations in the positions of three important groups suggest a political framework for this domestic history. The fortunes of the "pre-war nationalists" (civilians specializing in poli- 
tics and administration) follow those of the Republic. They are weak at the beginning but rise slowly to the first Dutch "police action." They then decline sharply after the second "police action," but recover dramatically after they succeed in negotiating a transfer of sovereignty.

The "pemuda" or younger generation find chief expression in military bodies. At the beginning, they exercise local control, but they suffer a sharp decline when civilian government becomes entrenched after the transfer of sovereignty. The "traditional elite" (sultans and chiefs in the Outer Islands and the administrative corps on Java) are severely weakened by the revolutionary radicalism of the early period, are restored as the leading social element in the Dutch federal state system, but are then seriously discredited after the transfer of sovereignty.

\section{Divination as Agent of Change in Tibetan Society}

\section{Robert B. Ekvall, University of Washington}

The Tibetan's need for divination derives to a considerable degree from the paucity of information media in his culture. As a device for looking into the future or across extended space, it presupposes an orderly universe in which the law of cause and effect is operative. In the context of Tibetan concepts of time and the nature of existence-absolute, relative, and delusory-divination appears a logical way in which to gain access to knowledge. In its many forms, it may be either preponderantly mechanical-as in the throwing of dice-or almost entirely subjective - as in prophecy. All divination can be subjectively slanted, and the lama practitioners who seek success gather data and carry out extensive research in order to be well informed and wise in the answers they give. Both the original request for divination and the compulsions of the diviner point toward change, or at least toward something more than the routine solution. As examples of this tendency, three instances of divination are described.

\section{The Spirit of Bargaining as the Basis} for Philippine Politics

\section{Jean Grossholtz, Mount Holyoke College}

The essence of political processes we define as democratic is the bargaining behavior which characterizes the interaction of roles and personalities in the political arena. The key role is that of the politician acting as a broker accommodating conflicting demands on national resources and translating these into public policy. The most important components of bargaining are trust and predictability, and these are the most difficult to build in a society in transition from an established traditional order to a modern state.

Research in the Philippines revealed that the system of raising children, strong family obligations, and the pattern of generational respect and religious structure contribute in important ways to the sense of trust and confidence the Filipino has in his ability to manipulate human relations. The Filipino's identity is bound up with his self-esteem, forcing him to learn manipulative techniques to overcome the dangers. In addition the required behavior teaches him that all negotiations involve a quid pro quo. The skills and behavior learned through socialization have been transferred to the political arena, providing the basis for a Philippine bargaining process. This system provides the rural masses with effective channels for their demands and is an effective means of political integration.

\section{Image Structure in Noh Plays \\ Roy E. Teele, University of Texas}

This study is based on the assumptions that: studies in Shakespeare's imagery by such scholars as Spurgeon, Clemen, Van Doren, and Heilmann have proved stimulating and rewarding; Ezra Pound's intuitive discovery of the "single image" in noh plays is suggestive though incompletely and in part inaccurately worked out; and Prof. Jinichi Konishi's brief study of stylistic elements in noh plays points the way for further examination of the image structure of these plays. The reiterated yet subtly changing imagery of temple bells and moonlight in Miidera, of moonlight and water in Matsukaze, and of the weary mountain journeyings in Yamauba all show a masterful handling both of evocative power and of development. This is true of a number of other plays, also by Zeami. On the contrary, the imagery in Kannami's Motomezuka and Kojiro's Momijigari is relatively fragmentary and undeveloped. Therefore, one test of Zeami's authorship of a play, like Soshi Arai Komachi for example, might be to show the unity of its imagery. In this case, the fact that virtually all the imagery of the play is related to poetry itself would point to Zeami as author, or to Zeami's having thoroughly revised the play.

\section{The Japanese Christmas: The Ideology of Affuence}

David W. Plath, University of California, Berkeley

In the past century, especially since the end of the Pacific War, an American-styled secular Christmas celebration has become widespread in Japan. Field data from central Nagano Prefecture 1959-60 show this: Christmas Day is not a legal holiday, but both public and private celebrations occur in various forms-decorations in the stores and streets, concerts, parties, giving of presents, acting out the visit of Santa Claus, etc. Cults and dramatizations of sentiment rarely can be explained in terms of a single motive, but the most promising line of explanation for the Japanese popular Christmas would seem to be that this "cult" fills a figurative "pattern gap" in traditional Japanese institutionalized expressions of feeling. It allows one to demonstrate one's faith that abundance and material well-being will continue-or at least should continue-for all.

\section{Post-War Shintoism in Japan}

\section{Toyoaki Uehara, Seton Hall University}

Since the end of the war, a broad new concept of religious freedom has been at work in Japan in contrast to the narrower concept which influenced Japan for many centuries. State Shinto was an extreme form resulting from the historical assumption that the government had the right to control religion. The broader concept stems from the policy of separation of religion and state instituted by the Occupation Forces and confirmed by the new Constitution. The activity of many newly-formed religions and well-established pre-war re- 
ligions is instilling this broader concept, and yet since the attainment of independence in 1952, there has been a trend toward seeking a return to some form of State Shinto as a means of preserving national identity.

Whether Japan will follow this trend depends on a proper understanding of the meaning of Shinto, which is a projection of the Japanese ethnic psyche. State Shinto is an unbalanced manifestation which results in an over-emphasis on the position of the shrines. If the broader concept is followed, the integrity of the Japanese ethnic psyche will be preserved without sacrificing any of its legitimate manifestations.

Self-Supporting Schools in Comzmunist China:

The "Half-Work, Half-Study Universities"

Robert D. Barendsen, U. S. Office of Education

In the summer of 1958 , a new educational institution which became known as the "Communist Labor University" was founded in Kiangsi Province. This school and a similar one known as "Industrial Labor University," established in early 1960, received considerable publicity in the mainland press as prototypes of a new kind of higher educational institution designed to operate on a half-work, half-study basis and to support itself with the proceeds of the half-time labor of its students. In this respect, these new institutions are the counterparts, on the higher educational level, of the highly touted "agricultural middle schools" which were set up beginning in 1958. Like the agricultural middle schools, these new "universities" are not comparable in quality to regular full-time institutions. But they are important manifestations of the Chinese Communist regime's attempts in recent years to make more training available to more people with less cost to the State. Understanding of the basic concepts involved in this approach and of the special problems encountered in implementing it, as illustrated by the half-work, half-study universities, is essential to comprehension of the strengths and weaknesses of the educational system in Communist China today.

\section{The Changing Pattern of Rural Communes in Communist China}

\section{Chu-yuan Cheng, Seton Hall University}

The rural commune system of Communist China, in its first three years (1958-1961), has undergone a series of drastic changes. The most important of these changes are the pattern of communal ownership, function, distribution of income, and the timetable of the transition from socialism to communism. Although the title of rural commune is still retained, the substance of the system has actually been completely altered.

In its first stage (April 1958-April 1959), the commune appeared as a comprehensive, all-round, all-inclusive socio-economic unit which could be considered as the embryo of the communist goal of distribution according to need. It showed strong intent to abolish all private ownership and the family system. In its second stage (April 1959-September 1960), the rural commune became the socialist ideal of collective ownership. On the basis of the former advanced co-operatives, the production brigades were allowed to be independent and the peasants were allowed to retain private plots and resume family life. In its present stage (after October 1960), the production teams have autonomy. Private labor also is respected and justified. Functionally, the agricultural system in China has not only retreated to the advanced co-operative stage, but further to the elementary co-operative stage.

\section{Moscow-Peking Relations in the Light of the 22nd CPSU Congress}

Peter S. H. Tang, Research Institute on the Sino-Soviet Bloc

With the savage Soviet attack on the leadership of the Albanian Workers' Party, Peking's conduct has been interpreted as a manifestation of deep-seated hostility to certain Soviet policies and practices. However, Communist China's firm and strenuous defense of the muchpublicized Communist principles of inter-Party independence and equality may have actually saved the Soviets from the pitfall of engaging in great-nation chauvinism. Hence, Peking considers it is making probably even a more significant contribution than it did during the I956 Hungarian and Polish uprisings to secure the healthy development and eventual complete victory of the international Communist movement.

It is possible that the present Sino-Soviet difference may come to transcend the limits which must govern any fraternal disagreement as they have been clearly outlined in the 1957 and 1960 Moscow statements. However, unless this does occur, the present situation must be regarded primarily as an example of differences in degree and emphasis, rather than over principle or basic Communist ideology. This analysis is reinforced by the Communists' own governing dialectical process - the theory of contradictions. Mindful of the value which they place on the constant struggle to resolve non-antagonistic contradictions as the sole means to progress, the West must avoid any unsupported conclu. sions that an irreparable Sino-Soviet break has become an imminent reality.

\section{The "Next Generation" of Chinese Communist Leaders Donald W. Klein, The Asia Foundation}

Communist China's elite leaders have reached an age where a new core of leadership is just over the horizon. The newcomers are products of the post-Sino-Japanese war; they will tend to hail from North China as opposed to Mao Tse-tung's core group from the CentralSouth. They have educational backgrounds comparable to those of the earlier leaders-three-fourths are collegetrained. They will continue to come from families of some means rather than from the peasant-proletariat ranks. However, they will not have the degree of personal contact with the non-Communist world as their predecessors inasmuch as far fewer have had experience abroad as students or as regime officials.

The Party machinery-as opposed to the government or military bureaucracies-will apparently be the most widely used avenue for advancement. Yet this supposition must be tempered by changing conditions which may bring about greater power for modern military planners more aware of the implications of nuclear warfare. Moreover, pressing economic difficulties may open 
paths for those working in "police" functions. With Mao's passing, the new leaders will probably lack a unifying leader. Finally, the elite will lose the talents of many non-Communist intellectuals who are rapidly dying off.

\section{The Economic Penetration of the Chinese in the Philippines, 1850-1898}

Edgar Wickberg, University of Kansas

Although Chinese had resided in the Philippines for many centuries prior to 1850 , their number had been limited and their areas of settlement restricted. Between I 850 and 1898 immigration and settlement were unrestricted, and the Chinese population became much larger than ever before. For the first time, Chinese settlement and economic enterprise reached every part of the Philippines. As rural retailers and collectors of export produce, the Chinese established their stores everywhere. An anti-Chinese reaction developed. For the first time, Filipino businessmen, beginning to rise before 1850, had been thrown into serious competition with the Chinese as a result of the unrestricted immigration since 1850 . Thus, although anti-Chinese cultural biases preceded 1850 , the economic origins of the anti-Chinese economic nationalism of the twentieth-century Philippines may be found in the half-century $1850-1898$.

\section{Asian Nationalism and the Overseas Chinese}

\section{Stanley Spector, Washington University}

Overseas Chinese can be seen as an extension of Chinese imperialism, often unconscious so far as the participants and the Chinese government are concerned, but more recently conscious, owing to crowded conditions in Taiwan and Communist ambitions. They can also be viewed as "barbarianized" Chinese, only vaguely identifiable as real Chinese. In many overseas Chinese communities a subtle struggle goes on between those who wish to infuse Chinese values into the local community, and those who wish to be more quickly absorbed into the larger society around them. Anti-Chinese feelings also become an important factor in the development of local nationalism.

The overseas Chinese have supplied intellectual and political leadership to important movements, including the original Chinese revolution, to which Asian nationalism owes much inspiration and guidance. In the I920's Chinese revolutionary propaganda was disseminated throughout Southeast Asia through the overseas Chinese, who set an example for local nationalists. Overseas Chinese also encouraged negative aspects of nationalism. They were convenient scapegoats, as outsiders against whom local nationalism could safely contend. Chinese presence and success raised the economic and social aspirations of local peoples, created envy, and furnished examples and skills.

The Overseas Chinese and Chinese Politics, 1899-19II Jung-pang Lo, University of Washington

Suffering from discrimination and exclusion and realizing that their unhappy condition was a reflection of the weakness of their homeland, the Overseas Chinese, during the first years of this century, organized themselves and played an active role in the political scene of
China in the hope of creating a strong and prosperous country. The reformers, led by K'ang Yu-wei, encouraged them to employ the power of popular opinion to bring about institutional changes while Sun Yat-sen's revolutionaries incited them to furnish financial support to and to participate in the revolts which culminated in the Revolution of I9II. The activities of the Overseas Chinese during this decade reveal that they prefer a strong, stable, and democratic government in China to a militantly aggressive regime and, instead of being opportunistic, as they have been characterized in the Western press, they highly esteem the ideal of $i$ (Mathew's Dictionary No. 3002), doing what one's conscience dictates as right, which prompted some of them to acts of altruism and sacrifice.

\section{Party Building in Upper Burma \\ Manning Nash, University of Chicago}

The competing national parties of Burma reach into the countryside to build a mass organization among the peasants. In the villages of Upper Burma political life takes its forms from the constitution of the local village, the ideas about power and authority in Burmese culture, and the ways in which villages are tied to the national community. Comparing the two chief types of villages, the mixed crop dry farming village, and the irrigated wet rice village, two patterns of peasant participation in politics emerge, tied to the social structure, ideas of pon, gon, and awza. In the mixed crop village, forty households joined the formal party organization. Those who join are either related to or clients of a man of pon power. He, in turn, is in contact with the party organization in the nearby urban center. Political life here is a trade between powers - the local powerful man and his followers and the regional and national powers. The form of political trade is a favor for the community and delivery of the vote. Little attention is paid to the ideology and program of the national parties. In the wet rice village, land has been redistributed by the government, and this had led to internal fighting and jockeying for power. Here there is no man of pon and hence a series of cross pressures as men compete for local power. Few people join the formal organization, for they do not want to be placed in one or another faction. But two small groups represent the national parties. Villagers are solicited by these groups and there is internal trading of votes for deeds. The two groups also attempt to compete in ideological terms.

The development of agitational, ideological politics is thus tied to the economic and political structure of the local societies and the role of previous national intervention in them. Fully developed rural political groupings apparently develop in the communities with less agreement on local power, with greater spatial mobility as in migration, and with economic demands for land, credit, and government aid. The smaller parties are more ideological and draw on villages and persons strongly dissatisfied with government patterns of power trades in the integrated village or in the context of factions.

\section{Tribal Integration in India}

Surajit Sinha, University of Chicago

The study of contemporary tribal groups living in the 


\section{ANNUAL MEETING ABSTRACTS}

relatively inaccessible hilly tracts of Central India provides us with insights into the traditional process of integration of these so-called tribal isolates with the civilization of India. The process usually begins with slow penetration of the tribal tracts by Hindu artisans and agriculturists and later on by traders, ritual specialists, and religious preachers. The interaction process gradually gathers momentum on a firm basis of economic symbiosis and moves on toward jajmani relations in ritual service and often to the emergence of localized chieftaincies or states. This rather smooth process of integration, which may not have been so smooth in specific cases, has been greatly aided by the ideology of cultural pluralism in the dominant intruders.

The existing channels of interaction between the "tribes" and the "peasants" have not often been taken into account by the Government of India in her eagerness to integrate the so-called isolated tribes with Indian nationhood. These well-meaning efforts, strangely enough, have often led the tribes to move further away from making a common cause with the rest of the Hindu castes in a region and to consolidate pan-tribal isolationist movements. These latter movements have also been stimulated by the special allocation of "tribal" constituencies in the democratic elections.

\section{American Influence on Politics in Thailand}

Frank C. Darling, University of Colorado

American influence on politics in Thailand has contributed to the evolution of both democratic and authoritarian forces. From the early nineteenth century until 1947, American influence there helped spread a wider understanding of Western political and social values and arouse aspirations for a constitutional democracy. This liberalizing influence was exerted by American traders, diplomats, missionaries, advisers who had contact in Thailand, and Thai students who studied in the United States. Since 1947 this influence has been expanded largely by the economic aid, technical assistance, and educational exchange programs sponsored by the United States. This has resulted in larger numbers of Thai desiring some form of constitutional government and the protection of human rights.

However, the dominant United States influence since 1947 has been the large-scale military aid program which has enabled Thai militarists to seize the government by force, eliminate all internal political opposition, and attain unlimited political power. Authoritarian military rule was moderated to some extent until 1957 by a precarious triumvirate regime led by Phibun, Phao, and Sarit. Yet since then, Sarit has emerged as the dominant figure, and he has restored a modern form of absolute political rule.

The United States is partially responsible for this and for the destruction of the nascent democratic elements emerging after World War II. American policy in Thailand should be to assist the evolution of a more popularly based government to promote the long-range stability and progress of the country. American military aid should be reduced and non-military aid increased to enable liberal civilian groups to emerge in Thai society and gain political significance.
The American-Australian Mandate Problem 1919-1925

J. Chal Vinson, University of Georgia

America and Australia were unable in the period I919-1925 to achieve a satisfactory common policy toward mandated islands in the Pacific. At the Paris Peace Conference, America opposed Allied annexation of islands formerly held by Germany, fearing that such action would strengthen Japan's strategic posture in the Pacific. Australia, wishing to annex New Guinea and the Solomon Islands, refused to accept American policy. Compromise was achieved by devising three classes of mandates and awarding Class $\mathrm{C}$ mandates to Australia and Japan.

After the Paris conference, the United States demanded an open-door policy in all three classes. Japan, at the Washington Conference, agreed to this; but the Australian government insisted that security and the White Australia policy made the closed door necessary. Despite Secretary of State Charles E. Hughes' repeated pressures on the British government in 1921 and 1923 , the open door was rejected. The issue was discussed at the 1923 Imperial Conference, still with no compromise. By diplomatic note, the British government in I925 explained Australia's stand without meeting the American position. The American-Australian conflict resulted in confusion of purpose and made difficult the American policy of closely supervising Japan's trusteeship of Pacific Islands.

\section{Some Remarks on Scientific Achievement in Communist China}

\section{George B. Young, RAND Corporation}

China hopes to approach, in many important fields of science and technology, the most advanced levels attained in the world by 1967 . This paper reviews the scientific progress in contemporary China, by focusing attention on the science budget and the command decision of 1958 .

Assuming that the 1967 goal is to be pursued by the mature graduates of the new universities of science and technology and is to be backed or supported by a technically reconstructed industry, the review suggests that China will only have firmly established a base for such an attainment, but that it can be quite an impressive base. However, by maximum concentration of effort, China can perform a limited number of scientific feats in 1967 , especially those which can be performed merely with the support of a high-level state of the art in the unsophisticated technologies, and with the technical personnel trained since 1958 in the institutes of the China Academy of Science.

\section{Price Problem in Communist China's Foreign Trade \\ Feng-hwa Mah, University of Washington and the RAND Corporation}

The average unit values of twenty-four Communist Chinese export commodities to the USSR, and twentyfive Communist Chinese import commodities from the USSR, for the years 1955-1959, are computed to compare with the average unit values in trade between ( 1 ) the Soviet Union and other countries, and (2) Communist China and other countries, whenever the other 
data are available. The results of our preliminary analysis show: (a) For Communist China's imports, in most cases, the unit values in Soviet-Communist Chinese trade were higher than those in free countries' imports from the USSR; (b) In the case of Communist China's exports to the USSR, for roughly one-half of the commodities compared, the Sino-Soviet unit values were lower than those of free Europe's exports to the USSR. These findings seem to indicate possible price discriminations on the part of the USSR against Communist China. It is believed, however, that at least part of the "China differential" may be explained by high transport cost included in the average unit values.

\section{Industrial Production in Communist China Kang Chao, University of Michigan}

The official indexes of industrial production for Communist China have two serious defects: (I), they contain some serious upward biases; (2), they cannot be compared with industrial production indexes of Western countries because of the different method used in computing them. This paper presents independently constructed indexes to measure the industrial growth in Communist China.

The indexes cover 1949 to 1959 , with 1952 serving as both the comparison base and the weighting base. The index numbers are arithmetic means of physical output of industrial goods, as officially published by the Chinese Communist authorities. The weighting system used in this study is a hybrid one, with prices as intraindustry weights and wage bills as inter-industry weights.

Two series of indexes are obtained, one inclusive and the other exclusive of handicraft production. The new indexes have eliminated some of the upward biases embodied in the official indexes. For the period covered in this study, the industrial growth in Communist China as shown by the new indexes was only about half of that displayed by the official indexes. Even so, the new indexes show a quite impressive record of industrialization, but this industrial development is characterized by imbalance, both intertemporal and intersectoral.

\section{Land Tenure Patterns and Sugar Cane Production in the Philippines}

Norman W. Schul, University of North Carolina

This case study in geography analyzes tenure patterns and their effect on the production of sugar cane by the haciendas or the sugar cane farms in a Philippine sugar cane district. The objective is to determine the spatial relationships of land tenure factors affecting sugar cane production on the haciendas composing the Victorias Milling Company. This company and its associated farm lands, covering approximately 37,000 hectares with 23,000 hectares planted to sugar cane, are located in the northern plain and adjacent uplands of Negros Occidental Province in the central Philippines. By describing the patterns of land tenure and then statistically and cartographically analyzing the differences and similarities, a generalization for the effect of land tenure on sugar cane production by the individual hacienda can be stated.

The land tenure categories established for the farms were: (1) Planter-owner; (2) Planter-renter; (3) Corporation; and (4) Estate. These groupings were analyzed in a multiple regression equation which measured the relationship between the yield of sugar cane per hectare for each hacienda compared to various physical and cultural factors, including the land tenure situation. This analysis indicated that land tenure was not statistically significant in its effect on production. However, tenure should not be considered as unimportant to the production of sugar cane in the milling district since the social aspects of land tenure become especially significant because of the similarity of farming operations associated with all tenure groupings and the concentration of land ownership in the hands of a few.

\section{Marketing in India}

Leon V. Hirsch, United Research Services

In the typical Indian agricultural marketing chain, growers (or petty merchants who have purchased their crops from them) sell through selling agents in assembling markets. The selling agents deal, either directly or through brokers, with buying agents in distributing markets. Large wholesalers, subwholesalers, and retailers comprise the remainder of the marketing chain. Distribution of manufactured goods is similar except that buying agents do not play a prominent role.

Several observations can be made on Indian marketing. There is often no clear-cut specialization of distributive activities, either vertically, by successive levels of distribution; or horizontally, by types of goods handled. The considerable unemployment and underemployment in India and the ease of entry into marketing (for members of trading castes) leads to great overcrowding in the field. This makes for strong competition and heavy downward pressure on margins and returns.

Financial and distributive activities are frequently interrelated. Middlemen who finance producers frequently obtain the opportunity of marketing their output, thus realizing both a profit from distribution and interest. The Indian marketing sector performs services similar to those usually rendered in developed countries but with some shifts of emphasis. Indian middlemen, however, typically see themselves as traders buying at one price and selling at a higher price, rather than as businessmen whose return is compensation for their function of distributing goods. 